\title{
Dynamics of Nutrient Uptake from Foliar Fertilizers in Red Raspberry (Rubus idaeus L.)
}

\author{
Regina L. Reickenberg and Marvin P. Pritts \\ Department of Fruit and Vegetable Science, Cornell University, Ithaca, NY 14853
}

Additional index words. nitrogen, nutrition, potassium, rubidium

\begin{abstract}
The dynamics of nutrient uptake from foliar applied ${ }^{15} \mathrm{~N}$-urea and $\mathrm{Rb}(\mathrm{a} \mathrm{K}$ analog) were quantified in red raspberries. Both $\mathrm{N}$ and $\mathrm{Rb}$ in an aqueous solution were absorbed rapidly into the leaf and transported throughout the plant. In the greenhouse, about half of the urea and a third of the Rb were absorbed within 32 hours of application. The addition of a surfactant to the foliar solution reduced uptake, while solution $\mathrm{pH}$, time of application and leaf age had little effect. The lower leaf surface exhibited a faster rate of absorption than the upper surface, but the difference was not large. In the field, some foliar $\mathrm{N}$ appeared to have been washed off leaves and taken up by the root system; however, none of the foliar applications affected plant growth. We conclude that significant uptake of foliar applied $\mathbf{N}$ and $\mathrm{K}$ occurs in raspberry, but the absolute amount delivered through a single foliar application is small. The percentage of total plant nutrient supplied through a foliar application is reduced to $<5 \%$ over time as the plant grows, so multiple applications would be required to maintain levels significantly higher than would exist through root uptake alone.
\end{abstract}

Horticultural practitioners have realized for decades that foliar applications of fertilizers have potential benefits, including the possibility of supplying nutrients to the plant when soil conditions restrict root uptake, or during periods of rapid growth, when requirements may exceed root supply (Boynton, 1954; Swietlik and Faust, 1984). For example, foliar fertilizers are recommended for supplying $\mathrm{K}$ to prune and citrus trees on some clay soils where $\mathrm{K}$ is so fixed that plants become deficient even in the presence of large quantities of soil-applied K (Carlson and Uriu, 198 1; Page et al., 1963). Some growers routinely apply foliar fertilizers even when soil nutrient availability is unrestricted, assuming that higher levels in the plant will result in greater growth or yield.

Fruit crop responses to foliar applications of $\mathrm{N}$ and $\mathrm{K}$ have been inconsistent. Some positive responses in pome fruits and citrus have been documented, but stone fruits are less responsive (Boynton, 1954; Swietlik and Faust, 1984), and most experiments with berry crops have failed to measure growth or yield responses, except under extreme conditions (Albregts and Howard, 1986; Gur et al., 1979; Han et al., 1989; Leece and Kenworthy, 1971; Rosen et al., 1988; Shawa, 1982; Widders and Hancock, 1994; Yogaratnam and Greenham, 1982; Zilkah et al., 1987).

We were interested in examining the uptake dynamics of foliar applied $\mathrm{N}$ and $\mathrm{K}$ in raspberry for several reasons. First, little is known about the effectiveness of foliar nutrient applications in raspberry. Although the subject of foliar fertilization has been extensively reviewed (Boynton, 1954; Kannan, 1980; Swietlik and Faust, 1984; Weinbaum, 1988; Wittwer and Teubner, 1967), we are aware of only one study involving raspberries (Norton, 1976), and in this study, neither yields nor foliar levels of nutrient elements were affected. Second, raspberries are a high value crop, so many growers routinely apply foliar nutrients to nutrient-sufficient plants believing that this practice could be beneficial and economical, despite any empirical evidence. We were interested in quantifying the uptake of foliar macronutrients in raspberry to learn if sufficient

Received for publication 26 Apr. 1995. Accepted for publication 6 Sept. 1995. We acknowledge the assistance of Mary Jo Kelly and Jessica Arnold with data collection and plot maintenance. Lucia Tyler, Mary Jo Kelly, and Warren Stiles provided helpful reviews. Supported in part through Hatch project NYS 142-402. Fruit and Vegetable Science Paper no. 58. The cost of publishing this paper was defrayed in part by the payment of page charges. Under postal regulations, this paper therefore must be hereby marked advertisement solely to indicate this fact. nutrient could enter the leaf to make a physiological difference to the plant.

The objectives of this study were to quantify the absorption kinetics of $\mathrm{N}$ and Kin the raspberry plant; determine the fate of foliar applied fertilizers; determine if absorption can be enhanced by modifying the nutrient solution or environmental conditions; and monitor the movement of absorbed nutrient. We used ${ }^{15} \mathrm{~N}$ and $\mathrm{Rb}$ as tracers to study nutrient absorption through leaves of raspberry.

${ }^{15}$ Nitrogen is a stable isotope of nitrogen and is rare in nature. BY using fertilizers labeled with ${ }^{15} \mathrm{~N}$, movement of $\mathrm{N}$ can be monitored in both soil and plant tissue. $\mathrm{Rb}$ is considered to be an effective tracer for $\mathrm{K}$, and has been used as a $\mathrm{K}$ analog in plant nutrition studies for many years (Collander, 1941). Rb and $\mathrm{K}$ are similar in ionic size, diffusion coefficients, and other chemical properties. $\mathrm{Rb}$ is relatively rare in soils, and does not have the physiologically detrimental properties of $\mathrm{Na}$, which also has a similar chemistry. Plant roots are believed to absorb Rb and K indiscriminately (Baligar et al., 1979).

\section{Materials and Methods}

The cultivar 'Heritage' was used in the following experiments for three reasons: 1) 'Heritage' is among the most popular cultivars in the world, 2) primocane-fruiting types such as 'Heritage' remain in a vegetative state for most of the first growing season, so nutrient requirements and sufficiency levels are expected to remain relatively constant, and 3) 'Heritage' plants are usually grown for a fall crop only, so potentially complex interactions with floricanes are avoided.

Foliar uptake kinetics from leaf surfaces. The objective of this experiment was to determine the uptake kinetics of $\mathrm{N}$ and $\mathrm{Rb}$ applied to the upper leaf surface, the lower leaf surface, or both surfaces.

Tissue culture plugs of 'Heritage' primocane fruiting raspberries were planted in 16-cm-diameter pots on 4 Apr. 1991. The rooting medium consisted of 2 montmorillomite/illite baked clay $: 1$ coarse sand (by volume). The plants were placed outdoors on a gravel surface. A trickle irrigation system was used with 75 to 100 ppm $\mathrm{N}, \mathrm{P}$, and $\mathrm{K}$ from water soluble fertilizer to provide water and nutrients.

The overall nutrient status of the plants was determined on 24 June 1991 by collecting a composite sample of 25 fully expanded 
leaves. An ICP argon plasma atomic emission spectrophotometer (ICP, Jarrell-Ash, Franklin, Mass.) and microKjeldahl nitrogen analysis of a block digestion were used to quantify tissue nutrient concentrations. The results of the leaf analysis were: $\mathrm{NH}_{3}-\mathrm{N}, 4.5 \%$; $\mathrm{K}, 2.4 \%$; P, 0.52\%; Ca, 1.1\%; Mg, 0.49\%; Mn, 88 ppm; Fe, 161 ppm; Cu, 6.1 ppm; B, 46 ppm; Zn, 29 ppm; Mo, 2.6 ppm; Al, 72 ppm; and $\mathrm{Na}, 30 \mathrm{ppm}$, indicating that plants likely were not deficient in any nutrient (Pritts and Handley, 1989).

On 24 June 1991, 108 plants were moved into the greenhouse and spaced at $1 \times 1 \mathrm{~m}$ on the floor. The first two fully expanded leaves were marked using a small ring of adhesive tape around the petioles; these leaves would serve as experimental units.

To nondestructively determine the amount of solution that would be applied to each leaf at runoff, the relationship between retained spray volume and leaf area was determined before the application of treatments. A hose was attached to an atomizer and inserted into a graduated cylinder containing a known volume of solution. Ten leaves were sprayed individually to runoff over a pan, and the runoff was collected and returned to the graduated cylinder. The difference in spray volume was then regressed on leaf area as determined by a portable leaf area meter (LI-COR, Lincoln, Neb.). Regressions were calculated for both the upper and lower leaf surfaces treated separately, and for both surfaces. Correlation coefficients were all significant and ranged from 0.65 to 0.90 . These regressions then were used to estimate the amount of spray retained on the leaf for the $\mathrm{Rb}$ applications and, hence, the amount of $\mathrm{Rb}$ applied. Because of the expense involved with ${ }^{15} \mathrm{~N}$, the nitrogen solution was not applied to runoff. Rather, a micropipette was used to apply a constant $200 \mu$ liter of solution to similarly-sized leaves.

On 25 June 1991, beginning at $0930 \mathrm{HR}$, applications of $\mathrm{N}$ or $\mathrm{Rb}$ were made to the upper surface of the leaf only, to the lower leaf surface only, or to both leaf surfaces. One of the two marked leaves on each plant received a $\mathrm{N}$ treatment and the other received a $\mathrm{Rb}$ treatment.

The $\mathrm{N}$ solution consisted of $6.0 \mathrm{~g}$ of ${ }^{15} \mathrm{~N}$-labelled urea $(99.8$ atom $\%$ ) in one liter of water (a commercial rate) containing a $0.1 \%$ solution (v/v) of Tween 80 surfactant. The concentration of $\mathrm{RbCl}$ was $4.0 \mathrm{~g} \cdot$ liter $^{-1}$ and was applied to run-off. Conditions in the greenhouse at the time of treatment were $27 \mathrm{C}$ and $50 \% \mathrm{RH}$.

Nonwashed leaves from a minimum of 4 plants from each treatment were harvested at $\mathrm{O}, 1,2,3,4,8,14$, and $32 \mathrm{~h}$ after treatment, and their leaf area was determined. One half of the leaves in this sample was washed in distilled water (Reed, 1983), and all leaves were dried at 60C for about 1 week, after which dry weight was measured. ${ }^{15}$ Nitrogen concentrations were determined with a $\mathrm{C} / \mathrm{N}$ Analyser-Tracemass mass spectrometer (Europa Scientific, Crewe, U. K.) and $\mathrm{Rb}$ concentrations were determined with an ICP spectrophotometer described earlier. ${ }^{15} \mathrm{~N}$ concentrations in untreated leaves were subtracted from the levels in treated leaves before analysis.

The absorption model $\beta_{0} \times\left(1-\mathrm{e}^{-(\beta 1 \times \text { time })}\right)$ was used to describe the uptake curve where $\beta_{0}$ estimates the maximum percentage of applied nutrient retained in the leaf overtime and 13, describes how fast the curve reaches this maximum percentage. The dependent variable is the percent of the total applied nutrient that is retained in the leaf after washing as a function of time. Data analysis was done using a nonlinear regression procedure, and coefficients were compared using the studentized $t$ test (SAS Inst., Cary, N.C.)

Influence of environment on uptake kinetics. The objective of this experiment was to determine if solution $\mathrm{pH}$, effect of surfactant, leaf water status, leaf age, and time of application would affect the movement of nutrient into the leaves of nutrient-sufficient plants.
On 31 July 1991, a composite sample of 25 leaves was analyzed from first year tissue-cultured 'Heritage' plants to assess nutrient status. The results of the analysis were: $\mathrm{NH}_{3}-\mathrm{N} 2.5 \% ; \mathrm{K} 2.3 \% ; \mathrm{P}$ 0.30\%; Ca 1.3\%; Mg 0.43\%; Mn 106 ppm; Fe 114 ppm;Cu 4 ppm; B 38 ppm; Zn 21 ppm; Mo 1.4 ppm; Al 57 ppm; and Na 28 ppm. Plants likely were not deficient in any nutrient (Pritts and Handley, 1989). Eighty-eight raspberry plants were moved into the greenhouse and spaced at $1 \mathrm{~m}$ centers. The first fully expanded leaf was marked with a small piece of adhesive tape, and considered the experimental unit to which treatments were applied.

On 1 Aug. 1991, applications of foliar nutrients commenced at $1130 \mathrm{HR}$ and were completed by noon, except for treatments that would evaluate the effect of time of day on uptake. For $\mathrm{Rb}$, applications were made to runoff on both leaf surfaces with an atomizer, while a micropipette was used to apply $200 \propto \lambda$ of urea solution per leaf. At $1130 \mathrm{HR}$, greenhouse conditions were $21 \mathrm{C}$, $65 \% \mathrm{RH}$, and $190 \mu \mathrm{mol} \cdot \mathrm{m}^{-2} \cdot \mathrm{s}^{-1} \mathrm{PPFD}$.

Treatments. The standard N solution consisted of $3.6 \mathrm{~g}$ of ${ }^{15} \mathrm{~N}$ labelled urea (99.8 atom \%) in 1 liter of water. This solution had a $\mathrm{pH}$ of 8.5. Three other solution $\mathrm{pHs}$ were tested (5.0, 7.0 and 9.0). Acetic acid or $\mathrm{NaOH}$ was used to adjust $\mathrm{pH}$. An additional treatment consisted of the standard solution plus surfactant $(0.1 \%$ $(\mathrm{v} / \mathrm{v})$ Tween 80$)$. Each of these five treatments was applied to each of four leaves, except for the standard $\mathrm{N}$ treatment which was applied to 12 leaves.

The standard $\mathrm{Rb}$ solution consisted of $4.0 \mathrm{~g} \mathrm{RbCl}$ in one liter of water containing $0.01 \mathrm{~mm}$ sodium bicarbonate buffer. A weak buffer was required since the $\mathrm{pH}$ of this ionic solution was quite unstable. The addition of this buffer maintained the $\mathrm{pH}$ at 8.3, and was found not to affect uptake kinetics. Adjustments to $\mathrm{pH}$ were made using $\mathrm{NaOH}$ or $\mathrm{HCl}$ to obtain solutions with a $\mathrm{pH}$ of 5.0,7.0, and 9.0. A surfactant $(0.1 \%$ Tween 80$)$ was added to the standard solution as an additional treatment. Each of these five solutions was applied to three leaf units, except the standard Rb solution which was applied to eight leaf units.

The effect of leaf age on uptake also was examined in this experiment for both $\mathrm{N}$ and $\mathrm{Rb}$. The two leaves located at the fourth and fifth node down from the first fully expanded leaf were treated for comparison to the first fully expanded leaf of the standard treatment. Four replications of these older leaf units were used.

To determine the effect of plant water stress on the uptake of $\mathrm{N}$ and $\mathrm{Rb}$, the two standard treatments were each applied to four plants that had not been watered for $48 \mathrm{~h}$. Mean stomatal conductance of the eight water stressed plants was $1570 \pm 446 \mathrm{~cm} \cdot \mathrm{s}^{-1}$ before treatment, while that of eight randomly selected wellwatered ones was $2500 \pm 707 \mathrm{~cm} \cdot \mathrm{s}^{-1}$ (Porometer; LI-COR, Lincoln, Neb.) These stomatal conductance values were significantly different as determined by a t test $(P<0.01)$, and indicated that plants that had not been watered were under water stress.

In addition to the $\mathrm{N}$ and $\mathrm{Rb}$ treatments applied between 1130 and $1200 \mathrm{HR}$, applications of the standard solutions were made at 0600 , 1800, and $2400 \mathrm{HR}$. Conditions at $0600 \mathrm{HR}$ were 10C, 93\% RH, and $15 \mu \mathrm{mol} \cdot \mathrm{m}^{-2} \cdot \mathrm{s}^{-1} \mathrm{PPFD}$; at $1800 \mathrm{HR}, 25 \mathrm{C}, 85 \% \mathrm{RH}$, and 102 $\mu \mathrm{mol} \cdot \mathrm{m}^{-2} \cdot \mathrm{s}^{-1} \mathrm{PPFD}$; and at $2400 \mathrm{HR}, 14 \mathrm{C}, 96 \% \mathrm{RH}$ and 0 $\mu \mathrm{mol} \cdot \mathrm{m}^{-2} \cdot \mathrm{s}^{-1}$. There were four replicates of each of these treatments. In total, 10 variations of each nutrient solution were evaluated and compared.

Treated leaves were harvested $24 \mathrm{~h}$ after each treatment application. Area was determined for $\mathrm{RbCl}$ treated leaves, then leaves were washed in distilled water and dried in a forced air oven at $60 \mathrm{C}$. Analyses for $\mathrm{Rb}$ and ${ }^{15} \mathrm{~N}$ were performed as described previously.

Fate of foliar nutrients applied in the field. Sixty-four actively growing tissue-cultured plugs of 'Heritage' raspberry were planted 
at the Cornell Orchards, Ithaca, N. Y., 16 May 1990 at a $1 \times 2 \mathrm{~m}$ spacing. Soil was a Collamer fine silty loam (Glossoboric Hapludalf) with $3.9 \%$ organic matter and a pH of 6.1. Supplemental N and K were applied at planting at a rate of $34 \mathrm{~kg} \cdot \mathrm{ha}^{-1}$ and $55 \mathrm{~kg} \cdot \mathrm{ha}^{-1}$ as urea and potassium sulfate, respectively, based on standard recommendations and the $\mathrm{K}$ status of the soil.

Factors in the completely randomized experimental design were date of foliar application ( 1 Aug. or $1 \mathrm{Sept}$.), groundcover ( \pm black plastic), and excavation date. Each treatment combination consisted of 4 replications. One-half of the 64 plants were randomly selected and planted through a $1.0 \times 1.5 \mathrm{~m}$ sheet of black polyethylene $(0.08 \mathrm{~mm}$ thick). The black plastic was used to exclude the possibility of runoff and root uptake by foliar applied nutrients. Rainfall was adequate following planting, and trickle irrigation was installed in early June. The planting was cultivated and weeded by hand at regular intervals, and standard maintenance procedures were followed (Pritts and Handley, 1989). Plants appeared healthy and vigorous throughout the study.

On 1 Aug. 1990, 24 plants were treated with $5.4 \mathrm{~g}$ of ${ }^{15} \mathrm{~N}-$ labelled urea (21.2 atom \%) in one liter of water, a rate recommended for some fruit crops (Stiles and Reid, 1991). Another 24 plants were treated with $3.02 \mathrm{~g} \mathrm{RbCl}$ in one liter of water as recommended by Reed and Tukey (1987). About $100 \mathrm{ml}$ of solution was required to wet plants to runoff. The remaining 16 plants were treated on 1 Sept. 1990 with the urea solution when 200 $\mathrm{ml}$ was required to wet plants to runoff. Insufficient plants existed to treat in Sept. with an $\mathrm{RbCl}$ solution.

On 1 Aug. 1990, foliar nutrients were applied between 1145 and $1215 \mathrm{HR}$; at 23C and 61\% RH, under partly cloudy skies. On 1 Sept., foliar $\mathrm{N}$ was applied between 1200 and $1230 \mathrm{HR}$, at 27C and 35\% $\mathrm{RH}$, under sunny skies. Immediately after application, tape was placed on the top node of each plant to mark extension cane growth.

Four plants from each August treatment were excavated one week after application, one month after application, and at the end of the season. Plants treated in September were excavated one week and one month after application, corresponding to the end of the season (4 Oct.). Individual plants were excavated with a pitchfork, and soil was washed from roots. Plants were separated into roots, shoots, old leaves (leaves below the tape), and new growth (growth above the tape). Plant material was placed in paper bags, dried in an oven at $60 \mathrm{C}$, and analyzed for ${ }^{15} \mathrm{~N}$ and $\mathrm{Rb}$ as described previously.

Component tissue dry weight, tissue nutrient content, percent tissue nutrient from foliar fertilizer and percent recovery of foliar fertilizer were calculated and subjected to analysis of variance.

\section{Results}

Absorption kinetics. Absorption of the foliar nutrient was rapid soon after application, but decreased over the next several hours, reaching an asymptote within $24 \mathrm{~h}$ (Fig. 1). The amount of retained urea and $\mathrm{Rb}$ on nonwashed leaves was greater than the amount in washed leaves, but this difference progressively decreased up to about $24 \mathrm{~h}$ after application. The magnitude of the difference between washed and unwashed leaves after $32 \mathrm{~h}$ was greater for $\mathrm{Rb}$ than urea, averaging about $43 \%$ and $20 \%$, respectively (Table 1 ). The rate of absorption was greater for both $\mathrm{Rb}$ and urea when the solution was applied to the lower leaf surface $(\mathrm{P}<0.001)$.

These absorption kinetics were measured under conditions of $21 \mathrm{C}, 65 \% \mathrm{RH}, 190 \mu \mathrm{mol} \cdot \mathrm{m}^{-2} \cdot \mathrm{s}^{-1}$, at $1200 \mathrm{HR}$, on well-watered and fertilized micropropagated plants, with a solution of $\mathrm{pH}=8.5$ (urea) or $8.3(\mathrm{RbCl})$. The addition of a surfactant, changing solution $\mathrm{pH}$, time of application, water status of the plant, or leaf

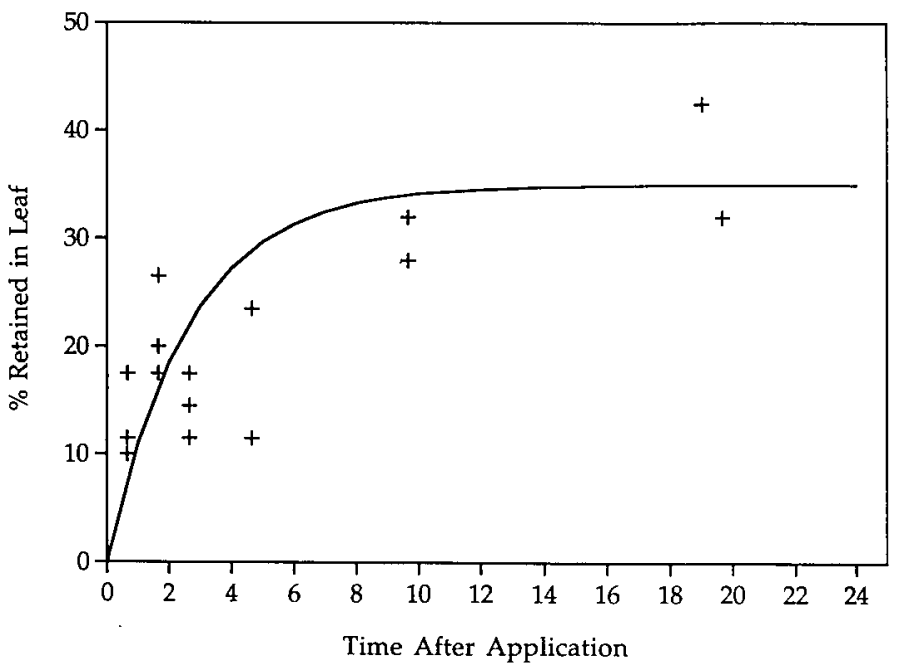

Fig. 1. Actual and predicted patterns of the retention of $\mathrm{Rb}$ applied to the top leaf surface of raspberry at $27 \mathrm{C}$ and $50 \% \mathrm{RH}$ on 25 June 1991 . Percent retained $=35 \%$ $\times\left(1-\mathrm{e}^{-(0.376 \times \mathrm{h})}\right), r=0.92, \mathrm{P}<0.01$.

Table 1. Parameters of regression curves modelling leaf retention of foliar applied nutrients over a $32-\mathrm{h}$ period.

\begin{tabular}{|c|c|c|c|c|}
\hline \multirow[b]{2}{*}{ Nutrient } & \multirow[b]{2}{*}{ Treatment } & \multicolumn{3}{|c|}{ Leaf surface } \\
\hline & & Top & Bottom & Both \\
\hline \multicolumn{5}{|c|}{$\begin{array}{c}\text { Asymptote coefficients (\% of total nutrient applied that is retained in } \\
\left.\text { leaf after } 32 \text { hours, } \beta_{i}\right)\end{array}$} \\
\hline \multirow[t]{3}{*}{$\mathrm{RbCl}$} & Washed & 35.1 & 42.0 & 27.2 \\
\hline & Nonwashed & 50.1 & 49.8 & 49.1 \\
\hline & & $* * *$ & $* * *$ & $* * *$ \\
\hline \multirow[t]{3}{*}{ Urea } & Washed & 25.8 & 35.4 & 27.0 \\
\hline & Nonwashed & 35.8 & 35.9 & 34.1 \\
\hline & & $* * *$ & NS & $* * *$ \\
\hline \multicolumn{5}{|c|}{ Extinction coefficients (rate of absorption, $\beta$, ) } \\
\hline $\mathrm{RbCl}$ & & 0.38 & 0.82 & 1.08 \\
\hline Urea & & 0.11 & 0.22 & 0.15 \\
\hline
\end{tabular}

***Significant at $\mathrm{P}<0.001$.

Table 2. Percent of retained nutrient after washing at $32 \mathrm{~h}$ under different environmental and solution conditions.

\begin{tabular}{lll}
\hline & \multicolumn{3}{c}{ Percent retained } \\
\cline { 2 - 3 } Treatment & Urea & $\mathrm{Rb}$ \\
\hline Standard & 45.7 & 33.2 \\
Surfactant & $29.3(-)$ & $22.2(-)$ \\
0000 HR & $30.7(-)$ & 27.5 \\
0600 HR & 43.1 & $45.2(+)$ \\
$1800 \mathrm{HR}$ & $35.3(-)$ & 29.1 \\
pH 5 & 45.4 & 28.4 \\
pH 7 & 37.2 & 28.8 \\
pH 9 & 38.4 & $25.8(-)$ \\
Older leaf & 44.3 & 38.8 \\
Water stress & 37.7 & 38.8 \\
LSD (0.05) & 8.8 & 6.8 \\
\hline
\end{tabular}

${ }^{+}$Significantly higher than the standard at $P<0.05$.

Significantly lower than the standard at $P<0.05$.

age did not increase the percent absorption of urea or Rb (Table 2). The only exception to this was the $0600 \mathrm{HR}$ application of $\mathrm{RbCl}$. Several treatments tended to decrease the percent absorption, 
Table 3. Percentage contribution of $\mathrm{N}$ from one foliar application of urea to total component $\mathrm{N}$ content over the season.

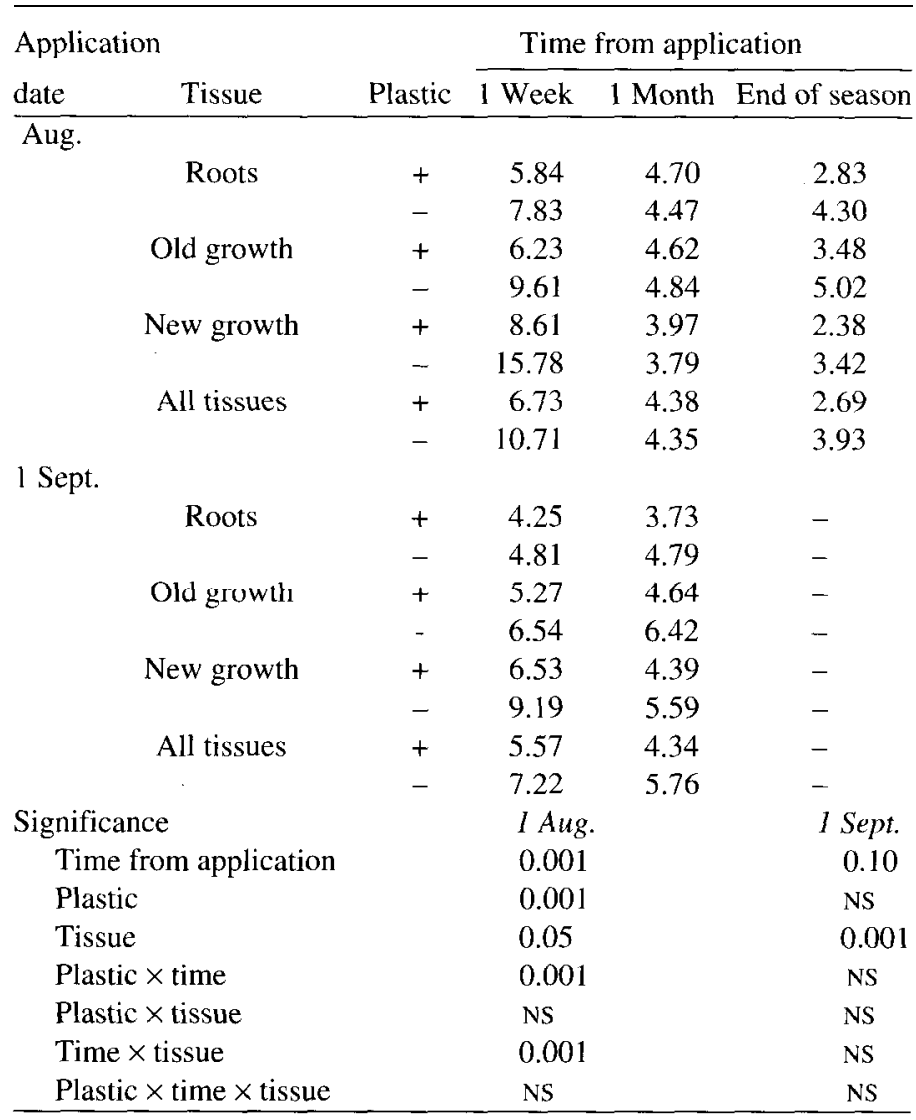

specifically evening applications and the use of surfactant.

Fate of foliar nutrients applied in the field. Under field conditions, recovery of foliarly applied $\mathrm{N}$ by the entire raspberry plant over the season was high $(59.2 \% \pm 4.3 \%)$, but was low for $\mathrm{Rb}$ $(7.0 \% \pm 0.9 \%)$. By 1 week after treatment, most of the recovered $\mathrm{N}$ was found in the roots $(51 \%)$, while most of the recovered $\mathrm{Rb}$ was in leaves $(67 \%)$. For both nutrients, the contribution of foliar applied nutrient to the total nutrient content of the plant was usually less than $10 \%$ for $\mathrm{N}$ (Table 3 ) and $20 \%$ for $\mathrm{K} / \mathrm{Rb}$ (Table 4) within a week of application. This percentage decreased overtime through dilution as plants continued to grow, so by the end of the season, the contribution of one foliar application to total plant nutrient content was less than $5 \%$.

In the field, nutrients that were absorbed through leaf tissue moved rapidly into new growth (Tables 3 and 4). In fact, new growth tended to have the highest concentrations of labeled nutrients within 1 week of application. Rb appeared to have less mobility than $\mathrm{N}$, but was still found at relatively high concentrations in new growth.

For N, there is evidence of leaf runoff and root uptake of the fertilizer, as plants contained less internal ${ }^{15} \mathrm{~N}$ when a plastic barrier was on the soil surface underneath the plant (Table 3). For Rb, there was no significant difference when the plastic barrier was in place (Table 4).

\section{Discussion}

One of the most important attributes of foliar fertilizers is the rapidity with which they can potentially deliver nutrients. Urea, in particular, is absorbed, translocated, and metabolized very rapidly
Table 4. Percentage contribution of $\mathrm{Rb}$ from one foliar application of $\mathrm{RbCl}$ in August to total component $\mathrm{K}+\mathrm{Rb}$ content over the season.

\begin{tabular}{|c|c|c|c|c|c|}
\hline \multicolumn{3}{|c|}{ Application } & \multicolumn{3}{|c|}{ Time from application } \\
\hline date & Tissue & Plastic & 1 Week & 1 Month & End of season \\
\hline \multicolumn{6}{|l|}{ 1 Aug. } \\
\hline \multirow{2}{*}{\multicolumn{2}{|c|}{ Roots }} & + & 13.3 & 4.18 & 1.67 \\
\hline & & - & 9.25 & 3.43 & 0.94 \\
\hline \multirow{2}{*}{\multicolumn{2}{|c|}{ Old growth }} & + & 15.8 & 3.97 & 1.75 \\
\hline & & - & 11.9 & 3.22 & 0.33 \\
\hline \multirow{2}{*}{\multicolumn{2}{|c|}{ New growth }} & + & 18.8 & 4.99 & 2.45 \\
\hline & & - & 15.8 & 4.52 & 1.66 \\
\hline \multirow{2}{*}{\multicolumn{2}{|c|}{ All tissues }} & + & 15.9 & 4.38 & 2.15 \\
\hline & & - & 12.2 & 3.78 & 1.27 \\
\hline
\end{tabular}

Significance

Harvest date

0.001

Plastic

Tissue

Plastic $\times$ date

Plastic $\times$ tissue

NS

0.001

Date $\times$ tissue

NS

NS

Plastic $\times$ date $\times$ tissue

0.01

NS

(Cooper et al., 1976; Hill-Nottingham and Lloyd-Jones, 1975; Klein and Weinbaum, 1984). Cain (1956) reported 80\% absorp tion of foliar urea by cacao leaves within $2 \mathrm{~h}$ of application. In tobacco, Volk and McAuliffe (1954) found foliar applied ${ }^{15} \mathrm{~N}$ in every plant part within 6 hours of application. Our study found that between a third and a half of the urea intercepted by the raspberry leaf was absorbed within $32 \mathrm{~h}$ and transported throughout the plant within 7 days.

Potassium also is absorbed and transported rapidly. In our greenhouse study, about one third of the $\mathrm{K}$ analog applied to the plant was absorbed into the leaf within $32 \mathrm{~h}$ and was transported throughout the plant within 7 days. Reed and Tukey (1978, 1987), Levi (1970), and Shafer and Reed (1986) have reported similar results. Although about 30\% retention of foliar applied $\mathrm{Rb}$ is common, our $\mathrm{Rb}$ uptake rates varied considerably between field and greenhouse, but the source of this variation is unknown.

Absorption of foliar applied urea by tobacco leaves has been shown to be almost identical through the upper and lower leaf surfaces, relatively unaffected by leaf maturity, but affected by leaf position (Volk and McAuliffe, 1954). Cook and Boynton (1954) found that absorption was faster on the lower leaf surface, and that older leaves were less efficient. Reed and Tukey (1987) showed that the absorption of foliar applied Rb compounds generally is unaffected by leaf age, while Widders and Hancock (1994) found that younger blueberry leaves contained more $\mathrm{N}$ derived from foliar sprays than mature leaves. We measured a slightly higher absorption rate on the lower leaf surface, but found no effect of leaf age.

Modifying the solution $\mathrm{pH}$, applying the fertilizer at different times of the day, or using water-stressed plants did not improve uptake. Some factors, including the addition of a surfactant, reduced uptake. Conditions that promote rapid drying of droplets, such as one might expect to occur with a surfactant, may reduce uptake. Absorption has been shown to be enhanced by humidity (Volk and McAuliffe, 1954), presumably because high humidity delays evaporation of the spray solution, thus providing a longer period for absorption. Reed and Tukey ( 1987) also found that the uptake of foliar applied $\mathrm{Rb}$ compounds was decreased by 18 commercially available surfactants, some of which were actually 
phytotoxic. Wittwer and Teubner (1967) concluded that surfactants seldom play a dominant role in mineral uptake.

Reed and Tukey ( 1978) examined the effect of $\mathrm{pH}$ on uptake of three $\mathrm{Rb}$ compounds by intact chrysanthemum plants, but found that over a range of 3-10, there was no difference in uptake. This is consistent with our findings. Although effects of solution $\mathrm{pH}$ have been reported (Swietlik and Faust, 1984), the differences are not large.

Time of day has been reported to have a profound effect on uptake of foliar applied urea. Volk and McAuliffe (1954) working with tobacco found that absorption was three to ten times greater during the night than during the day. They suggest that diurnal physiological fluctuations might explain this phenomenon. We found that uptake was reduced by midnight applications, but our diurnal patterns of variation were not of the magnitude reported by Volk and McAuliffe.

Water stress causes stomatal closure (Kozlowski et al., 199 1), so if the stomata play a major role in the uptake of foliar nutrients, then one might expect water stress to have a detrimental effect on foliar uptake. We found no such effect in raspberries, and could find no other examples of the effect of water stress on the uptake of foliar nutrients in the literature. Franke (1986) discounts the importance of the stomata in foliar uptake by noting that they are filled with gas, and therefore would require high pressure for a solute to penetrate them.

Our study indicates that aqueous solutions of foliar applied $\mathrm{N}$ and $\mathrm{Rb}$ are rapidly absorbed and translocated to both old and new tissues. Furthermore, our data suggest that absorption rates would not be improved significantly by modifying certain properties of the solution, such as $\mathrm{pH}$ or surface tension, or by applying the nutrient under different environmental conditions. So, although foliar applied macronutrients are rapidly absorbed and translocated, the question of their physiological effect must be addressed. In our study, no effect on growth was found from a single foliar application of $\mathrm{N}$ or K. Perhaps insufficient amounts of macronutrient can be applied in a single foliar application to affect the physiological status of the plant, at least when soil levels are sufficient and root uptake is not inhibited.

Based on cane density and dry weight measurements, we calculated that a mature raspberry planting would consist of about $114 \mathrm{~kg} \mathrm{~N} / \mathrm{ha}$ at the end of the growing season $(5710 \mathrm{~kg}$ dry matter/ ha $\times 2.0 \% \mathrm{~N}=114 \mathrm{~kg} \mathrm{~N} / \mathrm{ha}$ ). Assuming that $80 \%$ of a foliar application containing $5 \mathrm{~kg} \cdot \mathrm{ha}^{-1}$ urea is intercepted by the leaves, and $50 \%$ of that is absorbed into the leaf, then one foliar application would supply about $0.8 \%$ of the total $\mathrm{N}$ contained in the plant over the course of the season. A similar contribution to the total plant $\mathrm{K}$ requirement is indicated for $\mathrm{KCl}$ assuming a $33 \%$ rate of absorption. Since total plant $\mathrm{N}$ consists of current and reserve $\mathrm{N}$, the contribution of foliar $\mathrm{N}$ to current $\mathrm{N}$ would be higher in a mature planting. Even so, no data exist to show that $\mathrm{N}$ or $\mathrm{K}$ increases of this magnitude are physiologically significant when soil nutrient supply is adequate. In the field, our rate of recovery of $\mathrm{Rb}(7 \%)$ was lower than in the greenhouse $(40 \%)$, so if our field values are realistic, then foliar applied $\mathrm{K}$ would be expected to have only a small influence on total plant $\mathrm{K}$.

Some foliar urea fertilizer appears to run off the leaf and subsequently is absorbed by the root system. Rb did not show this tendency, perhaps because of its nearly 3-fold lower volubility in water and the tendency of soil colloids to bind $\mathrm{K}$ (and $\mathrm{Rb}$ ) ions. If soil $\mathrm{N}$ levels can be increased reasonably quickly with inexpensive granular fertilizers, then the added expense of foliar applications may not be warranted, even if plants are deficient.

Although foliar fertilization with macronutrients has proven to be beneficial under certain circumstances, there are no reports in the literature of positive benefits of foliar macronutrient applications in raspberry. Some commercial manufacturers and distributors have attributed a lack of response to improper formulations, plant water status, or time of day. However, we found reasonable absorption at any hour using water solutions without amendments. We suggest that the lack of response observed by raspberry growers to single foliar applications of macronutrients is due to the small amount applied in any one application. Furthermore, if plants already contain sufficient amounts of nutrients, then additional applications to the foliage would not be expected to elicit a physiological response. If soil uptake is restricted, then multiple foliar applications of $\mathrm{N}$ or $\mathrm{K}$ might be beneficial since a higher percentage is usually recovered from foliar applied compared to soil applied nutrients. Furthermore, the uptake dynamics of nutrient-deficient plants could be different than the nutrient-sufficient plants that we used in our studies.

\section{Literature Cited}

Albregts, E.E. and C.M. Howard. 1986. Response of strawberries to soil and foliar fertilizer rates. HortScience 21: 1140-1 142.

Baligar, V. C., N.E. Nielsen, and S.A. Barber. 1979. Kinetics of absorption of $\mathrm{K}, \mathrm{Rb}$, and $\mathrm{Cs}$ from solution culture by intact plant roots. J. Plant Nutr. $1: 25-37$.

Boynton, D. 1954. Nutrition by foliar application. Annu. Rev. Plant Physiol. 5:31-54.

Cain, J.C. 1956. Absorption and metabolism of urea by leaves of coffee, cacao, and banana. Proc. Amer. Soc. Hort. Sci. 67:279-286.

Carlson, R.M. and K. Uriu. 1981. Potassium in prune production, p. 98 99. In: Prune orchard management. Division of Agr. Sci., Univ. of California. Special Publ. 3269.

Collander, R. 1941. Selective absorption of cations by higher plants. Plant Physiol. 16:691-720.

Cook, J.A. and D. Boynton. 1954. Some factors effecting the absorption of urea by McIntosh apple trees. Proc. Amer. Soc. Hort. Sci. 56:82-90.

Cooper, D.R., D.G. Hill-Cottingham, and C.P. Lloyd-Jones. 1976. Distribution and identity of labeled products following autumn application of $15 \mathrm{~N}$-enriched urea or potassium nitrate fertilizers to apple trees. J. Sci.

Food Agr. 27:266-272.

Franke, W. 1986. The basis of foliar absorption of fertilizers with special regard to the mechanism, p. 17-25. In: A. Alexander (ed.). Foliar fertilization. Martinus Nijhoff, Dordrecht, The Netherlands.

Cur, A., J. Hepner, and Y. Shulman. 1979. The influence of root temperature on apple trees. IV. The effect on the mineral nutrition of the tree. J. Hort. Sci. 54:313-321.

Han, Z., X. Zeng, and F. Wang. 1989. Effects of autumn foliar application of ${ }^{15} \mathrm{~N}$-urea on nitrogen storage and reuse in apple. J. Plant Nutr. 12:675685.

Hill-Cottingham, D.G. and C.P. Lloyd-Jones. 1975. Nitrogen-15 in apple nutrition investigations. J. Sci. Food Agr. 26: 165-173.

Kannan, S. 1980. Mechanisms of foliar uptake of plant nutrients: Accomplishments and prospects. J. Plant Nutr. 2:717-735.

Klein, 1. and S.A. Weinbaum. 1984. Foliar application of urea to olive: translocation of urea nitrogen as influenced by sink demand and nitrogen deficiency. J. Amer. Soc. Hort. Sci. 109:356-360.

Kozlowski, T.T., P.J. Kramer, and S.G. Pallardy. 1991. The physiological ecology of woody plants. Academic Press, Toronto.

Leece, D.R. and A.L. Kenworthy. 1971. Effect of potassium nitrate foliar sprays on leaf nitrogen concentration and growth of peach trees. HortScience 6:171-173.

Levi, E. 1970. Penetration, retention and transport of foliar applied single salts of Na, K, Rb, and Cs. Physiol. Plant. 23:811-819.

Norton, R.A. 1976. Nutritional status of red raspberries in relation to leaf feeding. Proc. Wash. Hort. Assn. 66:121-127.

Page, A. L., J.P. Martin, and T.J Ganje. 1963. Foliar absorption and translocation of potassium by citrus. Proc. Amer. Soc. Hort. Sci. 82: 165-171.

Pritts, M. and D. Handley. 1989. Bramble production guide. Northeast 
Reg. Agr. Eng. Serv., Ithaca, N.Y.

Reed, D.W. 1983. Methods to assay absorption of foliar applied nutrients and removal of unabsorbed residue. J. Plant. Nutr. 6:667-677.

Reed, D.W. and H.B. Tukey. 1978. Effect of $\mathrm{pH}$ on the foliar absorption of rubidium compounds by chrysanthemum. J. Amer. Soc. Hort. Sci. 103:815-817.

Reed, D.W. and H.B. Tukey. 1987. Factors affecting foliar absorption of nutrients by selected landscape and herbaceous plants. J. Environ. Hort. 5:72-76.

Rosen, C. J., E.E. Hoover, and J.J. Luby. 1988. Influence of foliar-applied N-P-K fertilizers on productivity and nutrition of June-bearing strawberries. Can. J. Plant Sci. 68:277-282.

Shafer, W.E. and D.W. Reed. 1986. The foliar absorption of potassium from organic and inorganic potassium carriers. J. Plant Nutr. 9:143-157.

Shawa, A.Y. 1982. Response of 'McFarlin' cranberry to nitrogen sprays. HortScience 17:949-950.

Stiles, W.C. and W.S. Reid. 1991. Orchard nutrition management. Information Bulletin 219, Cornell Coop. Ext., Ithaca, N.Y.
Swietlik, D. and M. Faust. 1984. Foliar nutrition of fruit crops. Hort. Rev. 6:287-355

Volk, R. and C. McAuliffe. 1954. Factors affecting the foliar absorption of $\mathrm{N}^{15}$ labeled urea by tobacco. Soil Sci. Soc. Amer. Proc. 18:308-3 12. Weinbaum, S.A. 1988. Foliar nutrition of fruit trees, p. 81-100. In: P.M. Neumann (ed.). Plant growth and leaf applied chemicals. CRC Press, Boca Raton, Fla.

Widders, I.E. and J.F. Hancock. 1994. Effects of foliar nutrient application on highbush blueberries. J. Small Fruit Viticult. 2:51-62.

Wittwer, S.H. and F.G. Teubner. 1967. Foliar absorption of mineral nutrients. Annu. Rev. Plant Physiol. 10:13-32.

Yogaratnam, N. and D.W.P. Greenham. 1982. The application of sprays containing nitrogen, magnesium, zinc and boron to apple trees. 1. Effects on fruit set and cropping. J. Hort. Sci. 57:151-158.

Zilkah, S., I. Klein, S. Feigenbaum, and S.A. Weinbaum. 1987. Translocation of foliar-applied urea ${ }^{15} \mathrm{~N}$ to reproductive and vegetative sinks of avocado. and its effects on initial fruit set. J. Amer. Soc. Hort. Sci. 112:1061-1065. 